Historic, Archive Document

Do not assume content reflects current scientific knowledge, policies, or practices. 



\section{Seed Corn}

There is probably no cne thing that more vitally affects the prosperity of farmers of Henry and surrounding counties than seed corn. We carry in stock three varieties, Reid's Yellcw Dent, Krug, and Golden King, which after many trials in check plots and in fields, have been found outstanding as to their high yielding qualities and adaptability to Western lllinois conditions.

\section{Reid's Yellow Dent}

Too well known by farmers of lllinois and lowa to require much comment. Suffice to say our Reid's Yellow Dent was all grown from disease tested seed and is strictly a utility type. It has been grown here in Henry County for years. Our patent stock comes from such outstanding growers as Ed. Hulting, Geneseo; Henry Maeltzer, Osco.

\section{Krug}

Grown for years by Mr. Krug, a farmer of Woodford County, lllinois. Its high yielding qualities were discovered and brought before the public attention by Professor Moshier, of the University of Illinois, while employed as county farm adviser for Woodford County. Our patent stock is purchased each year from some of the growers and breeders of certified Krug corn. This parent seed is grown one year in Henry County to adapt it to Western lllinois conditions and the second year is released to our regular contract seed corn growers.

In test plots and field trials Krug corn is hard to beat, having a fashion of giving a good account of itself at husking time. This is evidenced by the repeat orders we receive each year from Eastern Nebraska and Central lowa customers. Krug corn is recognized as an outstanding variety over the corn belt.

\section{Golden King}

\section{(Early 100 D̃ay)}

For an early variety we have to offer you Golden King. This corn has for years been bred by W. L. Mills, McNabb, Illinois, grower and breeder of certified seed corn.

Our parent stock is purchased each year from Mr. Mills and is grown one year in Henry County to improve its adaptability, and the second year turned over to our contract growers.

Golden King, as its name denotes, is of a rich golden color, deep kernels, very free from starch, and highly disease-resisting, matures in 100 to 110 days.

Because of its high yielding, early maturing qualities, it is one of the outstanding early varieties grown in Henry County. 


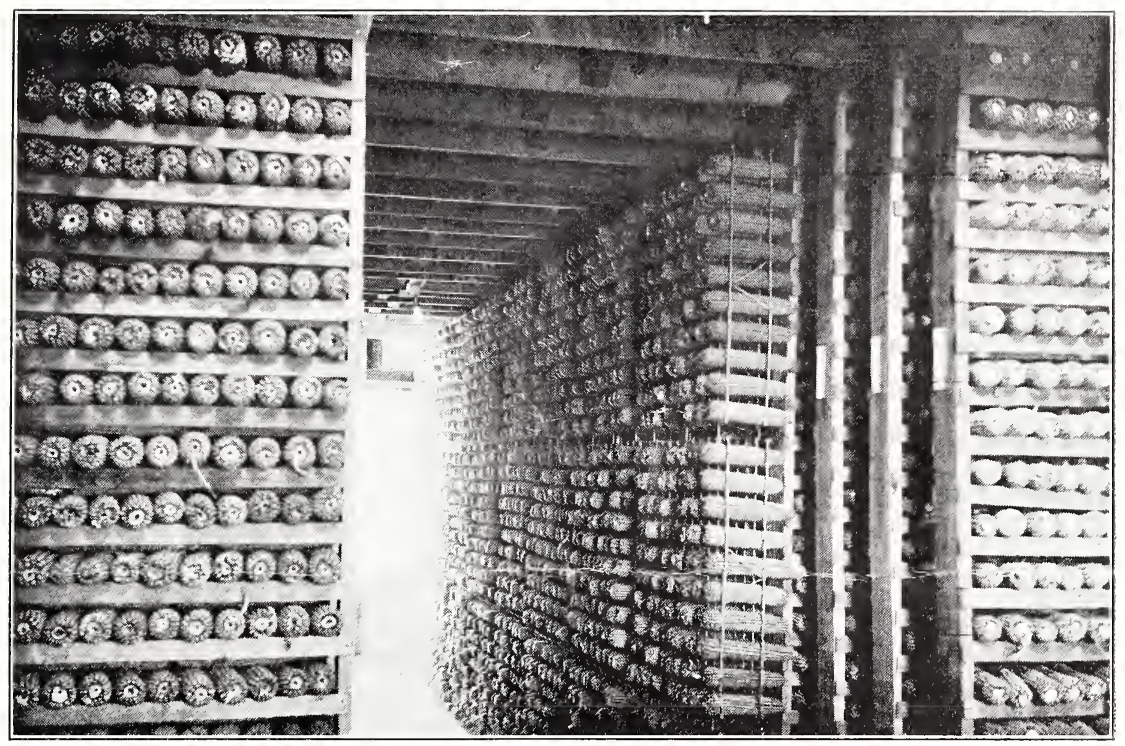

View in our Modern Seed House, showing method of storing and drying corn.

\section{Corn Grown From Tested Seed, Sack Picked and Properly Stored}

Our corn is all grown from disease tested seed by some of the leading farmers of Henry County. It is sack picked and placed on racks in our new corn storage house, where the moisture content is reduced to 13 to 15 per cent after which just a little heat is maintained during the winter months to keep the temperature at around 36 to 40 degrees.

\section{Test For Customers}

The Company last year installed a germinator for the disease testing of corn with capacity of 100 bushels. Besides doing our own disease testing we are doing considerable for outside parties. If you desire having us do some disease testing for you, write or phone in stating number of bushels you wish to have tested, and space will be reserved for you. Our price for this work is two dollars per hundred ears. 


\section{Field Seeds}

In the field seeds we carry a full line:

\begin{tabular}{ll} 
Mammoth Red Clover & Timothy \\
Medium Red Clover & Dwarf Essex Rape \\
Alsike & Sudan Grass \\
White Sweet Clover & Kentucky Blue Grass \\
Grundy County Sweet Clover & Orchard Grass \\
Yellow Sweet Clover & Spring Wheat \\
Alfalfa, Idaho & Barley \\
Alfalfa, South Dakota No. 12 & Soy Beans, Mancho \\
Alfalfa, South Dakota Grimm & Soy Beans, Ebony \\
\multicolumn{2}{c}{ Inoculation Cultures for Legumes }
\end{tabular}

\section{No Imported Seeds Sold}

We have never handled imported seed because much of it will not produce satisfactorily in this country. Where possible we have obtained seed locally but where this is impossible we have bought the best adapted seed available. We have tried to follow the recommendations of the University of lllinois and the U. S. Department of Agriculture on these lines.

\section{Agents Convenient For Customers}

Our seeds are in stock and for sale at the following places of business in Henry and adjoining counties:

O. W. Hoit Implement Company, Geneseo, Illincis.

Johnson \& Bollen, Geneseo, Illinois.

Ed. F. Zinser, Hooppole, Illinois.

Farmers Elevator \& Grain Company, Annawan, Illinois.

Farmers Elevator \& Grain Company, Kewanee, Illinois.

Sentz \& Company, Princeville, Illinois.

Stark County Farm Bureau, Wyoming, lllinois.

J. H. Duncan, Toulon, Illinois.

Keel \& Neville, Orion, Illinois.

Woodhull Grain Elevator Company, Woodhuli, Illnois.

Ophiem Grain Company, Ophiem, lllinois.

Mercer County Farm Bureau, Aledo, Illinois.

Rock Island County Farm Bureau, Rock lsland, Illinois.

We are never tco busy to show visitors our seed house and are glad of an opportunity to do so. If however, you find it inconvenient to visit us personally a written order will receive our prompt and careful attention.

\section{Farmers' Co-operative Seed Company Cambridge, Illinois}

